\title{
Financial Statements: An Interactive Learning Approach
}

\author{
Herbert E. Kierulff, (Email: hkierulf@spu.edu), Seattle Pacific University
}

\begin{abstract}
The often tedious but essential task of understanding financial statements and the inter-relationships among them can be enlivened by an interactive exercise with an unexpected and dramatic flair. I have used this approach for over ten years in both undergraduate and graduate finance and entrepreneurship classes, with entrepreneurs in Small Business Administration workshops, and with attendees at profit improvement planning workshops. The exercise begins with a four-quarter proforma income statement that shows a profitable, growing firm. Participants then create, with the instructor's guidance, the company's balance sheet that shows it unable to pay its bills by the end of the year. Then the participants discover for themselves how this seemingly contradictory situation can occur by developing, again with the instructor's guidance, a proforma cash flow. This paper demonstrates how the approach works and provides the materials used in the interactive session.
\end{abstract}

\section{INTRODUCTION}

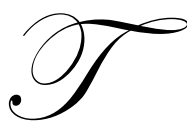

he lecture method is here to stay. No doubt about it. Studies of teaching and student preferences support the lecture method (Beard \& Hartley, 1984; Deberry, 1998).

Nevertheless, the lecture format continues to be open to criticism (Bouton \& Rice, 1983). Student attention spans show significant reductions after 20 minutes during lectures (Frederick, 1986; Stewart \& Rutherford, 1978). Michaelson (1983, p. 13) notes that: "students are forced to be passive; this produces apathy, absenteeism, and poor performance." Bales (1996) estimated that students remember long term only five percent of a traditional lecture, while retaining 50 percent of a discussion group and 75 percent of a practical exercise.

Studies in education indicate that interactive learning, which involves some level of active participation by students, is preferable to the one-way mode of lecturing. While the lecture method conveys information efficiently, students enjoy, retain, and understand material better when interactive learning is used. This is especially true when the teaching goals involve application, development of thinking skills, or changing attitudes (Biggs, 1996; Frederick, 1986; Karns, 2005; Murray \& Brightman, 1996; Reeves \& Francis, 2002). Participation creates excitement in the classroom (Bonwell \& Eison, 1991).

One school of thought holds that students construct their own knowledge rather than merely receiving it. Constructivist theory had its genesis in cognitive science, education, and psychology in the last century. It casts the teacher in the role of coach as opposed to a presenter of knowledge. The teacher poses realistic problems within meaningful contexts, and then facilitates learning through collaboration and reflection. The teacher also ensures that inconsistencies and errors in students' understanding are attended to (Kellar, Jennings, 1995; Springer \& Borthick, 2004).

My own experience over 35 years of teaching finance and entrepreneurship suggests that the lecture method is most effective when participants are actively engaged. One example of blending lectures with active learning is the Newco Case which I designed to be used in several venues. The first venue is with entrepreneurs who attend a Service Corps of Retired Executives seminar sponsored by the Small Business Administration. Most attendees are contemplating start-ups and the seminar is designed to acquaint them with the challenges of financial management. The second is with attendees in profit improvement planning workshops designed especially for financially troubled 
companies. I consult in this field and have found that approximately two thirds of my small business clients and most of the managers in larger firms have difficulty understanding the implications of their firms' balance sheets. The third is with students in the second course in finance at my university. These students have had courses in accounting and the first course in finance but need another look at key financials at the beginning of my course in financial analysis.

Newco can be used for a variety of purposes, including:

- $\quad$ Explaining or reviewing the definitions of financial statements and the line items in each.

- $\quad$ Demonstrating how the income statement, balance sheet, and cash flow are interrelated.

- $\quad$ Showing that profits and cash flow are not the same thing, and the implications of this point.

- $\quad$ Explaining that assets are what support sales; liabilities and net worth are what finance assets.

- $\quad$ Showing that cash flow can be found in the balance sheet (excess cash is cumulative net cash flow to equity).

- $\quad$ Demonstrating the extent to which the flow of cash relates to sales.

- Demonstrating how the cash flow statement is constructed from the income statement and balance sheet.

My approach is not problem based learning per se, but a derivative of it. It combines lecture with discussion, a method shown to be comparable with cooperative learning methods in terms of long term retention (Morgan, 2000). Bonwell (1996) makes the comment that "systematically incorporating brief active learning strategies into lectures minimizes many of the weaknesses of the lecture approach." In this paper, I explain the case and demonstrate its use.

\section{NEWCO INC. INCOME STATEMENT AND BALANCE SHEET}

At the beginning of the session I hand out the one page proforma financial statement depicted in Figure 1. I explain that Newco is a start-up with excellent potential and point out that the proforma income statement shows a potential profit of $\$ 25,000$. We (the participants and I) should get rich from this business and be able to take a vacation to an exotic location (Tahiti) by the end of the year.

Figure 1: Newco Inc. Financials (\$000)

$\begin{array}{lr}\text { INCOME STATEMENT } & \\ \text { Sales } & \$ 0.0 \\ \text { Cost of Sales: } .55 * \text { Sales } & 0.0 \\ \text { Gross Profit } & 0.0 \\ \text { Wages \& Salaries: Increase } \$ 10 \text { per Qtr. } & (10.0) \\ \text { Other Operating Expenses: } .20 * \text { Sales } & (10.0) \\ \text { Depreciation } & 0.0 \\ \text { Interest: } 7 \% \text { of Unpaid Balance } & 0.0 \\ \text { Profit Before Taxes } & (20.0) \\ \text { Taxes: .15 * Profit Before Taxes } & 3.0 \\ \text { Profit After Taxes (Net Income) } & (17.0) \\ \quad \text { Federal Income Tax Rate } & 0.15 \\ & \\ \text { BALANCE SHEET } & \\ \text { ASSETS } & \\ \text { Excess Cash } & 42.0 \\ \text { Operating Cash: } 12 \% \text { of Quarterly Sales } & 0.0 \\ \text { Accounts Receivable: One Month of Sales } & 0.0 \\ \text { Inventory: } 45 \text { days of Next Quarter's Cost of Sales } & 27.5\end{array}$

Quarter 2 Quarter 3 Quarter $4 \quad$ Total

$\begin{array}{rrrr}\$ 100.0 & \$ 200.0 & \$ 300.0 & \$ 600.0 \\ (55.0) & (110.0) & (165.0) & (330.0) \\ 45.0 & 90.0 & 135.0 & 270.0 \\ (20.0) & (30.0) & (40.0) & (100.0) \\ (20.0) & (40.0) & (60.0) & (130.0) \\ (3.0) & (3.0) & (3.0) & (9.0) \\ (0.5) & (0.5) & (0.5) & (1.6) \\ 1.5 & 16.5 & 31.5 & 29.4 \\ (0.2) & (2.5) & (4.7) & (4.4) \\ 1.3 & 14.0 & 26.8 & 25.0\end{array}$




\begin{tabular}{|c|c|c|}
\hline Total Current Assets & 69.5 & \\
\hline Net Fixed Assets & 70.0 & 67.0 \\
\hline TOTAL ASSETS & 139.5 & 67.0 \\
\hline \multicolumn{3}{|l|}{ LIABILITIES \& EQUITY } \\
\hline Accounts Payable: $1 / 2$ of Quarterly Cost of Sales & 0.0 & \\
\hline Accounts Payable: Next Quarter's Inventory Addition & 27.5 & \\
\hline Accrued Expenses: $4 \%$ of Quarterly Sales & 2.0 & 4.0 \\
\hline Accrued Federal Income Tax & $(3.0)$ & $(2.8)$ \\
\hline Current Portion LTD & 10.0 & \\
\hline Total Current Liabilities & 36.5 & 1.2 \\
\hline Long Term Debt (End of year payment) & 20.0 & \\
\hline Equity (Net Worth) & 83.0 & 84.3 \\
\hline TOTAL LIABILITIES \& EQUITY & 139.5 & 85.5 \\
\hline
\end{tabular}

Participants find it helpful to relate the financials to an actual business, such as a retail furniture store or a distribution company of some kind. This brings realism to the exercise and allows me to use actual examples when discussing line items such as inventory and fixed assets. I may take time to explain to the participants how to forecast and where they might find information to estimate costs and balance sheet entries. Often, participants will contribute if they have knowledge of information sources.

\section{CREATING THE BALANCE SHEET}

I explain that our first task is to develop the balance sheet from the data given and the assumptions to follow. Newco's first quarter begins January 1 and is devoted entirely to start-up activities. After that, sales grow rapidly in a stair step fashion. April through June's sales will be $\$ 33.3$ thousand each month; July through September's sales will be $\$ 66.7$ thousand each month; and so on. The use of quarterly data is for convenience (a 12 month set of financials would be unwieldy). I urge participants to create monthly proformas when they do their own plans to minimize stair stepping.

In addition:

- $\quad$ We (the participants and I) will invest $\$ 100,000$ in cash on January 2.

- We will borrow $\$ 30,000$ at the end of March and make equal principal payments each December $31^{\text {st }}$ over three years.

- We will have to buy fixed assets in the amount of \$70,000 at the end of March and begin depreciating them in the second quarter.

- I Include other assumptions that appear in the first column of Figure 1 and we deal with them as we examine each line item. Some of the entries in the first quarter's column are not consistent with their line item assumptions because of the nature of starting up.

- I will have the help of the participants in developing the balance sheet.

Participants now become active in the session in a "safe" role playing mode with instant feedback, an environment that enhances learning (Handfield-Jones et al, 1993). I urge them to work in pairs on their handouts if they wish. According to several studies, students appreciate handouts (especially incomplete ones), learn more because actively involved, and do better on exams (Butler, 1992; Beard \& Hartley, 1984; Feden, 1994). Perhaps the improvement in test scores is due to increased attention and motivation which enhances memory, as demonstrated by Mannison (1994). 
Papp \& Miller (1996) in their study on surgical teaching claim that the Socratic Method proved more stimulating to students. This is consistent with the case method approach practiced successfully for many years at Harvard and elsewhere. The Newco handout allows me to proceed by asking questions. What I do next depends upon the objectives of the session or sessions which are determined by the needs of the participants.

Most often, we move through the income statement quickly because the group is somewhat familiar with financial statements. In the income statement presentation, I emphasize the relationships of depreciation to fixed assets and interest to the debt. We then move to the balance sheet; it is here that most people have difficulty.

I define required cash as that inventory of cash in the bank and in the till essential to the operation of the business. With less than this amount, we run the risk of being overdrawn at the bank during some point in the quarter. I note that we have $\$ 42,000$ of excess cash at the end of March. Excess cash at the end of the year is what we will use to go to Tahiti in December. Or if we do miss our forecast, I claim that there will be plenty of money available as a safety net. Participants inevitably agree.

Accountants tell us that assets are what we own as a company and liabilities are what we owe to creditors and owners. We owe ourselves the net worth of the company since we own it. The balance sheet must balance, assets equaling liabilities and net worth, because what we own must be offset by what we owe. This sets the stage for a drama to be played out over the session if the instructor chooses to do so.

At this point, less knowledgeable participants find it helpful for me to observe that the income statement items start at zero at the beginning of each period (quarter). The balance sheet items carry over because they cumulate from quarter to quarter. Also, I emphasize that both statements record the company situation as it stands at the end of each quarter. I find the need to refer back to these points several times during the session.

I then ask the participants to pull out their calculators to help develop the balance sheet. They fill in the numbers in their handouts. I do the same on a computer spreadsheet which is projected on a screen in front of them. We take each line item in order, beginning with required cash. I put off covering excess cash until the end. If required cash should be 12 percent of quarterly sales, how much is that in the second quarter, the third quarter, the fourth quarter? I record their answers on the spreadsheet and we proceed to accounts receivable and then to inventory. Sometimes, participants ask why accounts receivable relates to current quarter sales and inventory to next quarter's sales. I stop and explain. Fixed assets are reduced by referencing depreciation in the income statement.

Then, I point out how rich we are becoming. I remind participants that assets are what we own. Over the year, we have amassed $\$ 307,000$ worth. In addition to that, we have $\$ 25,000$ in after tax profits. We are getting rich. Most heads nod in agreement, although some participants are becoming suspicious.

Developing liabilities and net worth seems to present the greatest challenge to those unfamiliar with accounting and finance. After some experimentation, I found it helpful to break up trade accounts payable into two parts. The first deals with credit on materials entering inventory and then shipped out during the quarter - the cost of sales. The second deals with credit on items being stored in inventory for future sales-inventory build-up. I make a point of relating this to the cost of sales in the income statement and to inventory in current assets.

Most people understand accrued expenses and accrued federal income tax and can see how these relate to the income statement. The debt line items present special difficulties. It takes some explaining and time line diagrams on a board or flip chart to show why the current portion of the long term debt should not drop to zero at the end of the year.

Figure 2 shows where we are at this point. 
Figure 2: Newco Balance Sheet (\$000)

ASSETS

Excess Cash
Operating Cash: $12 \%$ of Quarterly Sales
Accounts Receivable: One Month of Sales
Inventory: 45 Days of Next Quarter's Cost of Sales
Total Current Assets
Net Fixed Assets
TOTAL ASSETS

\section{LIABILITIES \& EQUITY}

Accounts Payable: 1/2 of Quarterly Cost of Sales

Accounts Payable: Next Quarter's Inventory Addition

Accrued Expenses: 4\% of Quarterly Sales

Accrued Federal Income Tax

Current Portion LTD

Total Current Liabilities

Long Term Debt (End of year payment)

Equity (Net Worth)

TOTAL LIABILITIES \& EQUITY

\section{$\begin{array}{llll}\text { Quarter } 1 & \text { Quarter } 2 & \text { Quarter } 3 & \text { Quarter } 4\end{array}$}

$\$ 42.0$

0.0

0.0

27.5

69.5

70.0

139.5

\begin{tabular}{rrrr}
0.0 & 27.5 & 55.0 & 82.5 \\
27.5 & 27.5 & 27.5 & 27.5 \\
2.0 & 4.0 & 8.0 & 12.0 \\
$(3.0)$ & $(2.8)$ & $(0.3)$ & 4.4 \\
10.0 & 10.0 & 10.0 & 10.0 \\
36.5 & 66.2 & 100.2 & 136.4 \\
20.0 & 20.0 & 20.0 & 10.0 \\
83.0 & 84.3 & 98.3 & 125.0 \\
139.5 & 170.5 & 218.5 & 271.4 \\
\hline
\end{tabular}

I turn to the group and announce: "Well, we're done." Hands (or voices) are raised. "The balance sheet doesn't balance." How this situation is handled depends upon the instructor's flair for the dramatic. My response is: "Oh, that's right. We have to figure out how much cash we're going to have for Tahiti."

We estimate the second quarter's ending cash as the difference between total liabilities and equity and total assets. The second quarter's excess cash is only $\$ 3,200$. I make sure that everyone realizes that this will be the actual amount of excess cash in the bank at the end of June if all goes as planned-we do not add $\$ 3,200$ to $\$ 42,000$. I feign slight concern but reassure everyone that we will make it up in the next quarter. Quarter 3 goes negative by $\$ 18,700$; Quarter 4 is even worse at negative $\$ 35,600$. I turn to the participants in mock shock: "How can you do this to us? You've taken a profitable company and turned it into a financial disaster."

\section{HOW DID THIS HAPPEN?}

I ask the participants: "How did this happen?" Now is the time for higher order thinking and discussion. How far this goes and how long depends upon the level of the class and time available. At the end of the discussion I summarize by noting that there is another way of thinking about assets, liabilities, and net worth. It is true that assets are what we own and liabilities and equity are what we owe. On the other hand, assets are what support sales, while liabilities and equity finance assets. The balance sheet must balance because we must have enough financing (liabilities and equity) to cover our asset needs.

In this case there is insufficient financing. Our need for operating cash, accounts receivable (to finance customers), and inventory (to maintain sufficient product) has outrun our sources of finance, i.e., current liabilities, long term debt, initial investment, and profits plowed back as retained earnings.

If more time is available, I suggest that a cash flow statement might help us understand why we are in difficulty. I provide a handout that is incomplete, and we work through the process in an interactive exercise to determine the source of the problem through cash flow analysis. Figure 3 shows the completed handout. I use this 
handout for finance students because it leads to free cash flow. This allows me to introduce discounted cash flow later on in the course.

\begin{tabular}{lrrrrr}
\hline & Figure 3: Newco Cash Flow - Format 1 (\$000) & & & \\
& Quarter 1 & Quarter 2 & Quarter 3 & Quarter 4 & Total \\
Beginning Cash & $\$ 100.0$ & & & & \\
Earnings Before Interest After Taxes (EBIAT) & $(17.0)$ & $\$ 1.8$ & $\$ 14.5$ & $\$ 27.3$ & $\$ 26.6$ \\
Plus: Depreciation & & 3.0 & 3.0 & 3.0 & 9.0 \\
Minus: Change in Working Capital & $(1.0)$ & $(43.1)$ & $(38.9)$ & $(36.6)$ & $(119.6)$ \\
Minus: Change in Investment & $(70.0)$ & 0.0 & 0.0 & 0.0 & $(70.0)$ \\
Equals: Free Cash Flow to Capital & 12.0 & $(38.3)$ & $(21.3)$ & $(6.3)$ & $(54.0)$ \\
Plus: Change in Debt Principal - Interest & 30.0 & $(0.5)$ & $(0.5)$ & $(10.5)$ & 18.4 \\
Equals: Free Cash Flow to Equity & 42.0 & $(38.9)$ & $(21.9)$ & $(16.9)$ & $(35.6)$ \\
$\quad$ Cumulative & 42.0 & 3.1 & $(18.7)$ & $(35.6)$ & \\
& & & & & \\
Change in Working Capital & & & & & \\
Operating Cash & 0.0 & 12.0 & 24.0 & 36.0 & \\
Accounts Receivable & 0.0 & 33.3 & 66.7 & 100.0 & \\
Inventory & 27.5 & 55.0 & 82.5 & 110.0 & \\
$\quad$ Total Operating Current Assets & 27.5 & 100.3 & 173.2 & 246.0 & \\
Accounts Payable Cost of Sales & 0.0 & 27.5 & 55.0 & 82.5 & \\
Accounts Payable Inventory buildup & 27.5 & 27.5 & 27.5 & 27.5 & \\
Accrued Expenses & 2.0 & 4.0 & 8.0 & 12.0 & \\
Accrued Federal / State Income Tax & $(3.0)$ & $(2.8)$ & $(0.3)$ & 4.4 & \\
$\quad$ Total Operating Current Liabilities & 26.5 & 56.2 & 90.2 & 126.4 & \\
& & & & &
\end{tabular}

I use the methodology in Figure 4 with entrepreneurs in SBA programs and elsewhere because the financial material available from that Agency follows this format.

\begin{tabular}{lrrrrr}
\hline & Figure 4: Newco Cash Flow - Format 2 $\mathbf{( \$ 0 0 0 )}$ & & & \\
& Quarter 1 & Quarter 2 & Quarter 3 & Quarter 4 & Total \\
& & & & & \\
CASH IN & $\$ 0.0$ & $\$ 66.7$ & $\$ 133.3$ & $\$ 200.0$ & $\$ 400.0$ \\
Current Quarter Sales: Collect 2/3 & 0.0 & 0.0 & 33.3 & 66.7 & 100.0 \\
Previous Quarter Sales: Collect 1/3 & 130.0 & 0.0 & 0.0 & 0.0 & 130.0 \\
Investment: New Debt \& Equity & 130.0 & 66.7 & 166.7 & 266.7 & 630.0 \\
$\quad$ Total Cash In & & & & & \\
& & & & & \\
CASH OUT & 0.0 & $(27.5)$ & $(55.0)$ & $(82.5)$ & $(165.0)$ \\
Current Qtr Accts Pay. 1/2* COS & 0.0 & 0.0 & $(27.5)$ & $(55.0)$ & $(82.5)$ \\
Previous Qtr Accts Pay. 1/2* COS & & $(27.5)$ & $(27.5)$ & $(27.5)$ & $(82.5)$ \\
Previous Qtr Accts Pay. Inventory Increase & $(18.0)$ & $(36.0)$ & $(62.0)$ & $(88.0)$ & $(204.0)$ \\
Current Quarter Operating Expenses & & & & &
\end{tabular}




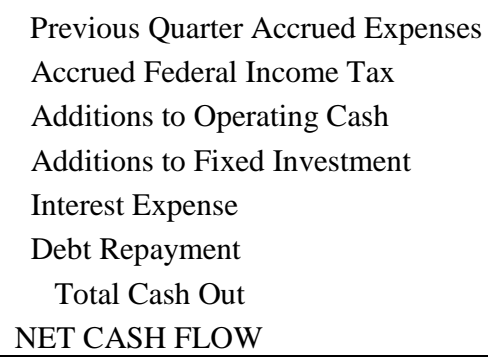

$(4.0)$

0.0

(12.0)

0.0

$(0.5)$

0.0

(188.5)

(21.9)
$(14.0)$

0.0

$(36.0)$

(70.0)

(665.6)

(35.6)

Figures 3 and 4, and to some extent 2, show that the working capital needs have outpaced the original equity and debt financing and profits. Much of this can be traced to rapid growth since, for the most part, operating working capital relates directly to sales. However, negative cash flow can result from a profitable company experiencing slower growth (or no growth). Figure 5 is an example in truncated form. My Company's cash problem comes about because of an increase in semi-variable costs, working capital, net fixed assets, and the payoff of long term debt. I use an example similar to this with audiences of businesspeople responsible for established companies.

Figure 5: My Company Financials (\$000)

\begin{tabular}{lrrrrr}
\hline & Figure 5: My Company Financials $\mathbf{( \$ 0 0 0 )}$ & & & \\
& & & & & \\
& Quarter 1 & Quarter 2 & Quarter 3 & Quarter 4 & Total \\
INCOME STATEMENT & & & & & \\
Sales & $\$ 100.0$ & $\$ 101.0$ & $\$ 102.0$ & $\$ 103.0$ & $\$ 406.0$ \\
All Costs & $(96.0)$ & $(97.0)$ & $(98.4)$ & $(99.4)$ & $(385.7)$ \\
Profit After Taxes (Net Income) & 4.0 & 4.0 & 3.6 & 3.6 & 20.3 \\
& & & & & \\
BALANCE SHEET & & & & & \\
ASSETS & & & & & \\
Excess Cash & 8.3 & 1.3 & $(5.8)$ & $(10.3)$ & \\
Operating Cash & 12.0 & 12.1 & 12.2 & 12.4 & \\
Accounts Receivable & 50.0 & 50.5 & 51.0 & 51.5 & \\
Inventory & 48.5 & 49.2 & 49.7 & 47.5 & \\
$\quad$ Total Current Assets & 118.8 & 113.1 & 107.1 & 101.0 & \\
Net Fixed Assets & 50.0 & 55.0 & 60.0 & 65.0 & \\
$\quad$ TOTAL ASSETS & 168.8 & 168.1 & 167.1 & 166.0 & \\
& & & & & \\
LIABILITIES \& EQUITY & & & & & \\
Current Payables & 28.8 & 29.1 & 29.5 & 29.8 & \\
Long Term Debt & 40.0 & 35.0 & 30.0 & 25.0 & \\
Equity (Net Worth) & 100.0 & 104.0 & 107.6 & 111.2 & \\
$\quad$ TOTAL LIABILITIES \& EQUITY & 168.8 & 168.1 & 167.1 & 166.0 & \\
\hline
\end{tabular}

\section{WHAT TO DO?}

Higher cognitive learning also comes from considering what we might do to solve the problem. There are several possibilities, each worthy of discussion. First, we could reexamine the cost structure of our proforma income statement to reduce costs. We might also reconsider each of our asset needs. Will we really require this much to support sales? Second, we could raise more cash. This suggestion gives me the opportunity to ask the question: when should we go to the banker or equity sources to raise cash - now, or when we need it in the third quarter? The 
obvious answer to this question allows me to discuss the importance of planning. We might not have realized the difficulty we will encounter if we had not prepared a plan prior to opening the business. After all, we start the business with $\$ 130,000$ in cash and loans, have only one loss quarter, and spend just $\$ 70,000$ on fixed assets. A third alternative is to slow our growth by charging more, advertising less, and so on. This alternative leads to a discussion of the counterintuitive behavior of cash flows over a cycle. Figure 6 demonstrates what can happen to excess cash when sales grow and then decline to $\$ 100$ per quarter with costs and balance sheet items following suit. Participants generally are surprised at the result, but understand after seeing how cost and asset requirements change.

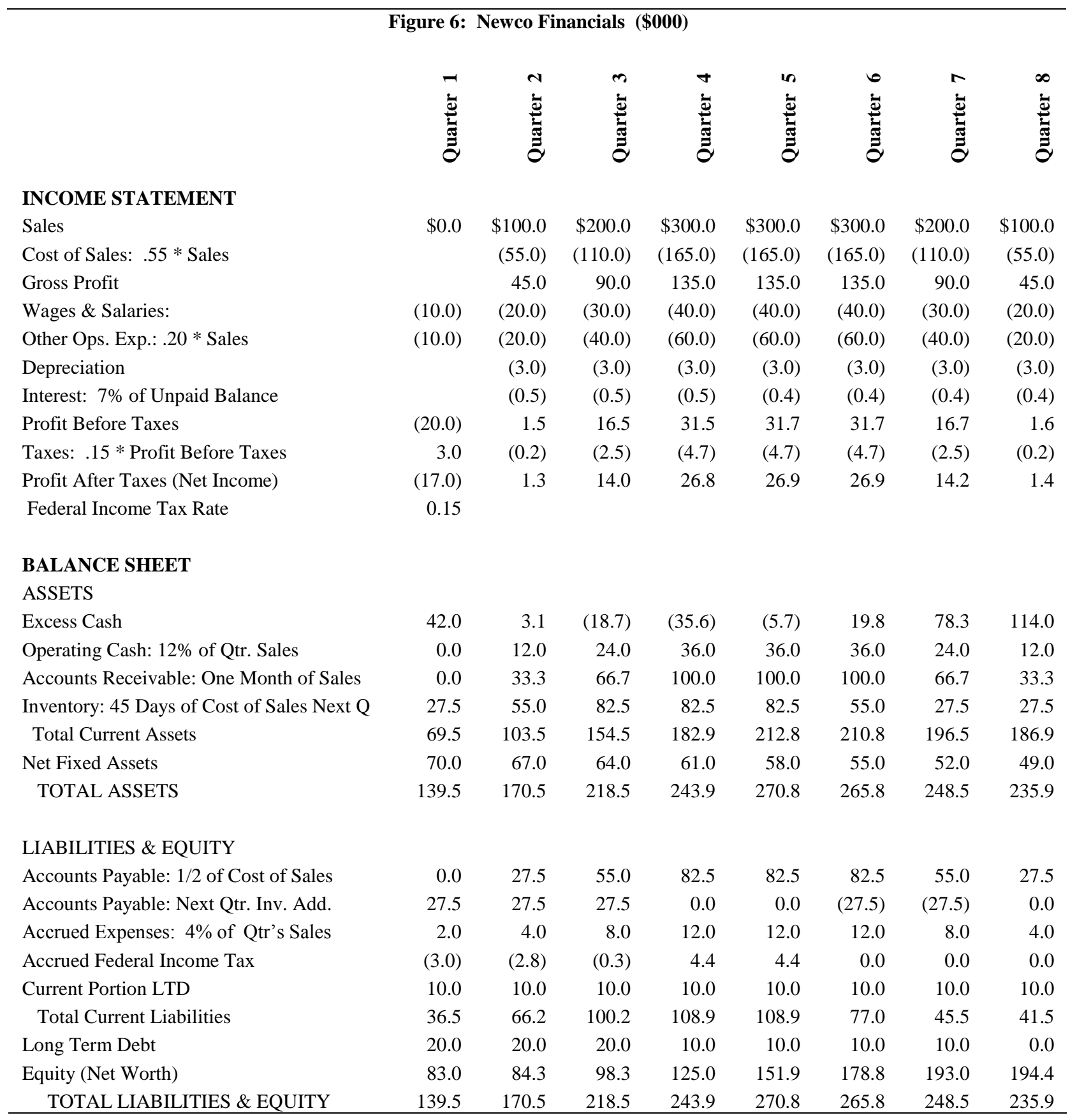




\section{CONCLUSION}

Research on teaching methods has demonstrated that the lecture method is effective. However, lectures can be enhanced by interactive exercises designed to keep participants directly involved and motivated. The Newco case has proven to be a versatile and useful pedagogical device for examining the relationships among income statements, balance sheets, and cash flows. The interactive nature of the case helps ensure participant attentiveness. The rather surprising turn of events when positive profit becomes a negative cash flow helps ensure that participants remember the experience and the lessons it teaches.

\section{REFERENCES}

1. Bales, E. (December, 1990). Corporate universities versus traditional universities: friends or foes. Paper presented at the Conference on Innovative Practices in Business Education, Orlando, Florida. In Van Dijk, L. A., G. C. Van Der Berg, \& H. Van Keulen (2001). Interactive lectures in engineering education. European journal of engineering education, 26(1), 15-28.

2. Beard, R. M. \& J. Hartley (1984). Teaching and learning in higher education ( $4^{\text {th }}$ ed.). London: Harper \& Row.

3. Biggs, J. B. (1996). Enhancing teaching through constructive alignment. Higher education, 32, 347-364.

4. Bonwell, C. C. (1996). Encouraging self-assessment: Writing as active learning. New directions for teaching and learning No. 67 (31-44). San Francisco: Josey-Bass, Inc.

5. Bonwell, C. C. \& J. A. Eison (1991). Active learning: creating excitement in the classroom (No. 1). Washington, DC: The George Washington University, School of Education and Human Development.

6. Bouton, C. \& B. Rice (1983). Developing student skills and abilities. In C. Bouton \& R. Garth (Eds.), Learning in groups (31-40). San Francisco: Jossey Bass, Inc.

7. Butler, J. A. (1992). Use of teaching methods within the lecture format, Medical teacher, 14, 11-25.

8. DeBerry. T. W. (1998). Teaching 'the dismal science' by the lecture method: maligned but not abandoned. International social science review, 72 (3/4), 67-75.

9. Feden, P. D. (1994). About instruction: Powerful new strategies worth knowing, Educational horizons, 73, 18-24.

10. Frederick, P. (1968). The lively lecture-8 variations. College teaching, 34, 43-50.

11. Handfield-Jones, R., L. Nasmith, Y. Steinert, \& N. Lawn (1993). Creativity in medical education: the use of innovative techniques in clinical teaching, Medical teacher, 15, 3-10.

12. Karns, G. L. (2005). An update of marketing student perceptions of learning activities: structure, preferences, and effectiveness, Journal of marketing education, 27(2), 163-171

13. Kellar, G. M., B. E. Jennings, H. L. Sink, \& R. A. Mundy (1995). Teaching transportation with an interactive method, Journal of business logistics, 16(1), 251-280.

14. Mannison, M., W. Patron, \& G. Lemon (1994). Interactive teaching goes to Uni: keeping students awake and learning alive, Higher education research and development, 13, 35-47.

15. Morgan, R. L., J. E. Whorton, \& C. Gunsalus (2000). A comparison of short term and long term retention: lecture combined with discussion versus cooperative learning. Journal of instructional psychology, 27(1), 5359.

16. Murray, R. \& J. R. Brightman (1996). Interactive teaching. European journal of engineering education, 21 (3), 295-309.

17. Reeves, J. A. \& S. A. Francis (2002). A comparison between two methods of teaching pharmacists about adverse drug reaction: problem based learning versus a didactic lecture. Pharmacy education, 1(1), 25-35.

18. Papp, K. K. \& E. B. Miller (1996). The answer to stimulating lectures is the question, Medical teacher, 18, 147-149.

19. Springer, E. W. \& A. F. Borthick (2004). Business simulation to stage critical thinking in introductory accounting: rationale, design, and implementation. Issues in accounting education, 19(3), 277-304.

20. Stewart, J. and R. J. D. Rutherford (1978). Medical school concentration during lectures. The lancet, 8088, 514-516. 


\section{NOTES}

